\title{
SUTURELESS VERSUS SUTURED CONJUNCTIVAL AUTOGRAFT FOR SURGICAL TREATMENT OF PTERYGIUM
}

\author{
By \\ Mohamed Khedr Mohamed, Mohamed Abd El-Badiea Rashed and \\ Mohamed Mahmoud Mohamed Hasan* \\ Ophthalmology Department, Faculty of Medicine, Al-Azhar University \\ *Corresponding Author: Mohamed Mahmoud Mohamed Hasan \\ Phone No.: 0201094225526 \\ E-mail: m_habib4444@yahoo.com
}

\begin{abstract}
Background: Pterygium is a degenerative ocular surface disorder with wing-shaped fibrovascular growth of the subconjunctival tissue onto the cornea.

Objectives: The purpose of this study was to compare the surgical outcomes of sutureless technique versus graft suturing technique for conjunctival autograft fixation following pterygium excision.

Patients and Methods: This prospective interventional case study included 20 eyes with pterygium requiring surgical excision. Operated eyes were divided into 2 equal groups. group A, where the conjunctival auto graft was placed without using sutures and with placing a tight bandage for 24 hours after excision, and group B where the conjunctival auto graft was fixed by $8 / 0$ nylon sutures.

Results: The surgical time for group A was significantly less as compared to group B. Postoperative symptoms were seen in less number of patients and were of shorter duration in group A as compared to group B. Recurrence rate and conjunctival granuloma formation rate for group A and for group B were statistically insignificant. Visual acuity and astigmatism showed improvement in both group with no statistically significant difference between both divided groups.
\end{abstract}

Conclusion: Suture-less and glue free limbal conjunctival autograft was safe, effective, economical, option for pterygium surgery.

Keywords: Sutureless Conjunctival Autograft, Sutured Conjunctival Autograft, Pterygium-stimulated astigmatism, operating time.

\section{INTRODUCTION}

Pterygium is a degenerative condition characterized by fibrovascular outgrowth of conjunctiva over the cornea. Many theories exist that try to explain its pathogenesis (Malozhen et al., 2017).

It can get inflamed, leading to redness and irritation in the area. In addition, the pterygium has the potential to progress to some ocular cancers, including ocular surface squamous neoplasia (Yeung et al., 2011).

The exact cause of pterygium is not known. Exposure to ultraviolet (UV) rays is perhaps the most common risk factor for the occurrence of pterygium (Bradley et al., 2010). 
It is speculated to be associated with corneal and conjunctival micro trauma from exposure to sunlight and/or dust. Thus, a higher prevalence of pterygium has been recorded among the outdoor workers, as compared to indoor workers in Nigeria, South India and Southwest China (Asokan et al., 2012).

Treatment thus far is exclusively surgical; however, pterygium often tends to recur aggressively. This has led to the use of sophisticated surgical techniques in an effort to reduce recurrence rates (Alkatrini et al., 2013).

Surgical removal is the main treatment for pterygia, and the surgical techniques can be divided into 3 types: (1) Bare sclera technique, in which no tissue grafing is used after pterygium excision (2) Simple closure, and (3) Tissue grafting technique, in which a conjunctival autograft, limbal conjunctival autograft, or amniotic membrane transplantation is used to cover the area from which the pterygium is excised (Janson and skider., 2014).

Fixation of the graft is most commonly done by suturing or with tissue adhesives. However, there are many drawbacks to suturing like prolonged operating time, postoperative discomfort, suture abscesses, buttonholes, and granuloma formation while the major concern of the commercial fibrin glue is the cost and the potential risk of transmitted infection (Singh et al., 2013).

Sutureless conjunctival autograft is a new, simple technique and economic option for pterygium management with few reported complications (Sharma et al., 2015).
The purpose of this study was to compare the surgical outcomes of sutureless technique versus graft suturing technique for conjunctival autograft fixation following pterygium excision.

\section{PATIENTS AND METHODS}

This was a prospective interventional study that included 20 eyes suffering from pterygium that warranted surgical removal for follow up after 3 months.

Operated eyes were divided into 2 equal groups:

Group A: the conjunctival autograft was placed without using sutures, and Group B: the conjunctival autograft was sutured by nylon sutures.

\section{Inclusion criteria:}

Primary pterygium Pterygium indicated for excision such as large fleshy pterigyum encroaching upon the pupil and causing high astigmatism. Patients $18-80$ years of age and both genders.

\section{Exclusion criteria:}

Patients unsuitable for or refusing a follow-up period of at least 3 months after surgery, presence of any symblepharon, glaucoma, previous ocular trauma or ocular diseases predisposing to ulceration or poor wound healing such as dry eye syndrome or rheumatoid arthritis.

\section{Pre-operative assessment:}

- History taking:

- Complete ocular examination:

- Visual acuity (VA): Without and with correction after doing refraction to obtain the best corrected visual acuity (BCVA). 


\section{SUTURELESS VERSUS SUTURED CONJUNCTIVAL AUTOGRAFT FOR...949}

- Slit lamp examination: Careful anterior segment examination was done to examine the pterygium whatever fleshy or fibrotic, its extent and encrochement over the cornea.

- Grades of pterygium growth onto the cornea are grade 1 (less than 2 $\mathrm{mm}$ ), grade 2 (2 to $4 \mathrm{~mm}$ ), grade 3 (more than $4 \mathrm{~mm}$ ), (Anbesse et al., 2017).

- Examination of the conjunctiva and fornices was done in order to exclude symblepharon and cicatrization.

- Ocular motility for any limitation.

- Photographic documentation of the pterygium.

- Laboratory assessment of blood sugar levels, bleeding time and clotting time to detect and exclude patients with abnormal results, which may impair healing.

- Obtaining an informed consent.

Post-Operative: Topical antibiotic and steroid combination eye drops were administered 4 times a day for 10 days and tapered over the next week. Lubricant eye drops were administered 3 times a day for 1 month. The patients were followed up post operatively after 24 hours, 1 week, 2 weeks, 4 weeks and then at 3 months. Slit lamp examination, refraction visual acuity and digital anterior segment photography were done to assess for complications and pterygium recurrence.

\section{Evaluation of Surgical Results:}

1. Operating time was recorded starting from the placement of the lid speculum to its removal at the end of the surgery.
2. The graft survival was defined as an intact graft by the fourth week after surgery, while graft loss was defined as the absence of the graft by the fourth week. Also graft retraction and granuloma formation will be assessed.

3. The subjective symptoms of patients including stitching pain, foreign body sensation and lacrimation were questioned at every follow up.

4. Occurrence of complications including: Early complications as:

- Sub conjunctival hemorrhage.

- Primary failure will be defined as graft dislocation during the first week or late complications as:

- Granuloma.

- Recurrence of the pterygium will be defined as the presence of fibro vascular tissue regrowth extending onto clear cornea within the followup period.

\section{Statistical methods:}

Data were coded and entered using the statistical package SPSS (Statistical Package for the Social Sciences) version 25. Data was summarized using mean, standard deviation, median, minimum and maximum in quantitative data and using frequency (count) and relative frequency (percentage) for categorical data. Comparisons between quantitative variables were done using t-test.

For comparing categorical data, Chi square (c2) test was performed. Exact test was used instead when the expected frequency was less than 5. P-values less than 0.05 were considered statistically significant. 


\section{RESULTS}

Operative data of the studied groups:

\section{A. Duration of operation:}

The duration of surgery was noted in each patient in both groups. There was a statistically significant difference in the operative duration between the two groups (p value 0.001), with the duration being much longer in suture group (Table 1).

Table (1): Difference between the sutureless and sutured group in the duration of surgery

\begin{tabular}{|l|c|c|c|c|c|}
\hline \multirow{2}{*}{ Groups } & \multicolumn{2}{|c|}{ Sutureless group A } & \multicolumn{2}{c|}{ Suture group B } & P value \\
\cline { 2 - 6 } Parameters & Mean & SD & Mean & SD & \\
\hline op. duration (min.) & 24.70 & 3.50 & 31.50 & 3.81 & 0.001 \\
\hline
\end{tabular}

\section{B. Intra-operative:}

Intra-operative sub conjunctival hemorrhage was noted in each patient in both groups. Table 2 shows the difference between group A and group B which was also greater in the suture group. However,
There was a statistically insignificant difference in the intra operative sub conjunctival hemorrhage occurrence between the two groups with $(\mathrm{P}$ value $>0.05$ ) (Table 2).

Table (1): Difference between group $A$ and group $B$ in intra operative sub conjunctival hemorrhage

\begin{tabular}{|c|c|c|c|c|c|}
\hline \multirow{2}{*}{ Groups } & \multicolumn{2}{|c|}{ Sutureless group A } & \multicolumn{2}{c|}{ Suture group B } & P value \\
\cline { 3 - 6 } & Count & $\%$ & Count & $\%$ & \\
\hline $\begin{array}{c}\text { Intra operative sub Conjunctival } \\
\text { hemorrhage }\end{array}$ & 3 & $30.0 \%$ & 5 & $50.0 \%$ & $>0.05$ \\
\hline
\end{tabular}

Post-operative data of the studied groups:

\section{Post-operative stitching pain:}

All patients experienced stitching pain in first day post operatively but, after one week, there was marked decrease in stitching pain noted by patients in sutureless group. Pain sensation declined markedly by the end of the first month and was not detected by the end of follow up there was a statistically insignificant difference in postoperative stitching pain between the two groups ( $p$ value $>0.05$ ) as represented in Table 3.

\section{Post-operative lacrimation:}

Post-operative lacrimation noted by patients was also greater in the suture group on day1 and on day 7. This complaint disappeared afterwards. There was statistically insignificant difference in postoperative lacrimation between the two groups on day1 and on day 7 as represented in Table 3 .

Post-operative foreign body sensation:

Post-operative foreign body sensation was noted by patients in both groups .It was also greater in the suture group on day1, day 7 and one month postoperative as represented in Table 3 .

There was a statistically insignificant difference in postoperative foreign body (F.B.) sensation between both groups in day 1 ( $\mathrm{p}$ value $>0.05)$ and in day 7 ( $\mathrm{p}$ value $>0.05)$. 
SUTURELESS VERSUS SUTURED CONJUNCTIVAL AUTOGRAFT FOR... 951

Table (2): Shows the difference in postoperative stitching pain ,lacrimation and foreign body sensation between group $A$ and group $B$

\begin{tabular}{|c|c|c|c|c|c|}
\hline \multirow{2}{*}{ Parameters Groups } & \multicolumn{2}{|c|}{ Sutureless group A } & \multicolumn{2}{c|}{ Suture group B } & P value \\
\cline { 2 - 6 } & Count & \% & Count & \% & \\
\hline Pain day 1 & 10 & $100.0 \%$ & 10 & $100.0 \%$ & --- \\
\hline Pain day 7 & 1 & $10 \%$ & 6 & $60 \%$ & $>0.05$ \\
\hline Pain month 1 & 0 & $0 \%$ & 2 & $20 \%$ & $>0.05$ \\
\hline Pain month 3 & 0 & $0 \%$ & 0 & $0 \%$ & --- \\
\hline lacrimation day 1 & 6 & $60 \%$ & 10 & $100 \%$ & $>0.05$ \\
\hline lacrimation day 7 & 0 & $0 \%$ & 2 & $20 \%$ & $>0.05$ \\
\hline lacrimation month 1 & 0 & $0 \%$ & 0 & $0 \%$ & --- \\
\hline FB sensation day 1 & 6 & $60 \%$ & 10 & $100.0 \%$ & $>0.05$ \\
\hline FB sensation day 7 & 1 & $10 \%$ & 5 & $50 \%$ & $>0.05$ \\
\hline FB sensation month 1 & 0 & $0 \%$ & 1 & $10 \%$ & $>0.05$ \\
\hline FB sensation month 3 & 0 & $0 \%$ & 0 & $0 \%$ & -- \\
\hline
\end{tabular}

Only one patient had graft loss in the sutureless group $(10 \%)$. However, the incidence of such complication showed no statistically significant difference between the two groups (Fig.1).

\section{Graft failure at day 1}

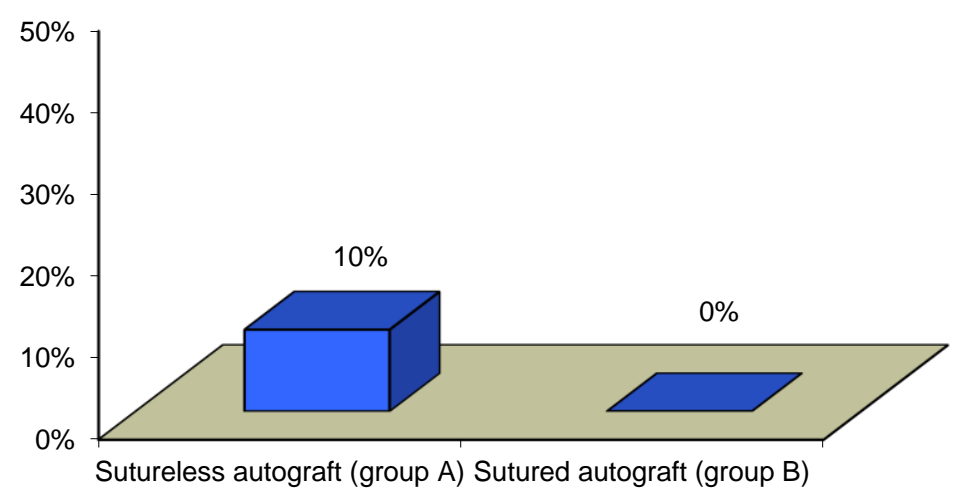

Figure (1): Postoperative graft loss among the studied group day 1

In our study the use of CAG with the patient's own blood coagulum has proven to be a successful method for pterygium excision.
Our study showed that the surgical duration was less in the sutureless group than sutured group and there was a statistically significant difference in between the two groups. 


\section{DISCUSSION}

Pterygium excision with conjunctival autograft has exhibited good results as it maintains the ocular surface even and restores the anatomy which existed before the corneal invasion caused by the pterygium. Anchoring of the graft to the denuded scleral bed can be done by sutures such as Vicryl or by means of tissue glues (Tissue adhesives.) Both techniques yield excellent results for reducing the number of recurrences in this type of surgery. In addition, greater patient comfort in the first few days after surgery is also a benefit. Pterygium excision with autologous conjunctival grafting seems to be the best method for pterygium removal, giving both low recurrence rate, safety and greater patient comfort (Bhatia et al., 2017).

In the current study, the conjunctival autograft was placed in group A using compression without sutures while in group B the graft was sutured. It was found that the sutureless technique showed a shorter duration of surgery than sutured technique. There were no recurrences in the sutureless group and less post-operative symptoms such as pain lacrimation and foreign body sensation.

Likewise other studies also assessed the use of sutureless auto graft in pterygium excision the first was done by Elwan (2014), who showed that recurrence rate was $6 \%$ in sutureless group and $8 \%$ in suture group, graft retraction was $8 \%$ in sutureless group and granuloma formation was $3 \%$ in suture group 2.

Sharma (2015) showed that surgical time was shorter in the sutureless group than sutured group. They showed a statistically significant difference in the postoperative stitching pain and postoperative lacrimation between the two groups being greater in the suture group on day 1 and day 7 this is mostly due to the irritation of sutures and more manipulation in group B.

Chanrda (2017) showed a statistically significant difference in pain, foreign body sensation and lacrimation between the two groups. The sutureless group having a significantly lower pain levels.

Similarly in Sharma et al. (2015) and in Chandra et al. (2017), showed that surgical time required to perform pterygium excision was shorter in the sutureless group than sutured group. This was similarly reflected on the amount of post-operative inflammation and pain.

Similarly, Elwan (2014) found that the intensity of the postoperative complaints including pain, foreign-body sensation, irritation was significantly lower in patients treated with the sutureless technique than in those treated with sutures at both postoperative day 1 and 7 days. Also, the intensity of foreign body sensation at the first two postoperative visits was lower among patients in the sutureless group than in the suture group.

Chandra et al. (2017) showed a statistically significant difference in pain, foreign body sensation and lacrimation between the two groups. The sutureless group having a significantly lower pain levels as shown.

In our current study, only one had graft loss case occurred in the sutureless group and could be due to persistent eye rubbing during the immediate postoperative period. 


\section{SUTURELESS VERSUS SUTURED CONJUNCTIVAL AUTOGRAFT FOR... 953}

Sharma et al. (2015) and Chandra et al. (2017) showed no graft loss in both groups.

Chandra et al. (2017) showed that one case show graft edema in both groups. In our study graft edema not assessed post operatively.

In our study no recurrence occurred in both groups during the first three months.

Elwan (2014), showed 3 cases of recurrence in sutureless group from 50 eyes and 8 cases recurrence in suture group from 100 eyes. This number of recurrences is much greater than in our study and is mostly due to larger sample of patients and longer follow up period. Sharma et al. (2015) showed one case recurrence in suture group.

Chandra et al. (2017) showed no recurrence of cases in both groups this may be due to small number of patients included in their study.

In our study there were no granulomas in the post-operative follow up in the two groups. However, Elwan (2014) study, showed granuloma in suture group and no cases in sutureless group which may be also due to large number of cases in that study 100 eyes by suture technique and 50 by sutureless technique.

Sharma et al. (2015) and Chandra et al. (2017) showed only one case in which a granuloma was detected in the postoperative follow up in the suture group.

As for visual outcome, in group A, $60 \%$ showed improvement of visual acuity and $70 \%$ in group B, but the difference was not a statistically significant in between the two groups.
Elwan, (2014) showed that the gain in uncorrected visual acuity (UCVA) occurred 3 months post operatively. 8\% were from sutureless group and $6 \%$ were in suture group. All cases with a gain in UCVA were due to clearance of visual axis occupied by pterygium preoperatively.

In our study, there was a decrease in astigmatism post operatively in both groups but this difference was not statistically significant in the postoperative astigmatism between the two groups.

Astigmatism was not analyzed in most of the other similar studies. However Altan-Yaycioglu et al. (2013) showed that the preoperative and postoperative keratometric measurements, evaluated using an automated keratorefractometer, were noted, and in all groups there was also an improvement in astigmatism.

\section{CONCLUSION}

Suture-less and glue free limbal conjunctival autograft was safe, effective, economical, option for pterygium surgery. Surgical outcomes were comparable to conventional suture limbal conjunctival autograft with lower post-operative suture related complications, less patient discomfort and greater patient satisfaction.

\section{REFERENCES}

1. Alkatrini K. C, Demetrios A. S, and Efestathios T. D. (2013): Viral involvement in the pathogenesis and clinical features of ophthalmic pterygium.Int J Mol Med, 32(3): 539-543.

2. Altan-Yaycioglu R., Kucukerdonmez C., Karalezli A., Corak F. and Akova Y. A. (2013): Astigmatic changes following pterygium removal: Comparison of 5 
different methods. Indian Journal of Ophthalmology, 61(3): 104-116.

3. Anbesse DH, Kassa T, and Kefyalew B. (2017): Prevalence and associated factors of pterygium among adults living in Gondar city, Northwest Ethiopia. Plos one,12(3): 202-210.

4. Asokan R., Venkatasubbu R. S., Velumuri L., Lingam V., and George R. (2012): Prevalence and associated factors for pterygium and pinguecula in a South Indian population. Ophthalmic and Physiological Optics, 32(1): 39-44.

5. Bhatia, J., Varghese, M., Narayanadas, B., and Bhatia, A. (2017): Cut-and-place technique of pterygium excision with autograft without using sutures or glue: Our experience. Oman Journal of Ophthalmology, 10(2): 81-83.

6. Bradley, J. C., Yang, W., Bradley, R. H., Reid, T. W. and Schwab, I. R. (2010): The science of pterygia. British Journal of Ophthalmology, 94(7): 815-820.

7. Chandra, N., Sinha, S. K., and Kumar, S. (2017): Conjunctival autografting with and without sutures in pterygium-A comparative study. Laterality, 6(4): 5-20.
8. Elwan, S. A. (2014): Comparison between sutureless and glue free versus sutured limbal conjunctival autograft in primary pterygium surgery. Saudi Journal of Ophthalmology, 28(4): 292-298.

9. Janson B. J. and Sikder S. (2014): Surgical management of pterygium. Ocul. Surf., 12, 112-119.

10. Malozhen SA, Trufanov SV and Krakhmaleva DA. (2017): Pterygium: etiology, pathogenesis, treatment Vestn Oftalmol., 133(5):76-83.

11. Sharma A, Raj H, and Raina A. (2015): Suture Less and Glue Free Limbal Conjunctival Autografting following Pterygium Excision. JK Science, 17(2): 6872.

12. Singh, P. K., Singh, S., Vyas, C. and Singh, M. (2013): Conjunctival autografting without fibrin glue or sutures for pterygium surgery. Cornea, 32(1): 104-107.

13. Yeung, S. N., Kim, P., Lichtinger, A., Amiran, M. D., Cote, E., Teitel, S., and Slomovic, A. R. (2011): Incidence of ocular surface squamous neoplasia in pterygium specimens: an 8-year survey. British Journal of Ophthalmology, 13(4):61-69. 
SUTURELESS VERSUS SUTURED CONJUNCTIVAL AUTOGRAFT FOR... 955

\section{مقارنة استخدام تقتية الترقيع الذاتي للملتحمة بدون خياطة

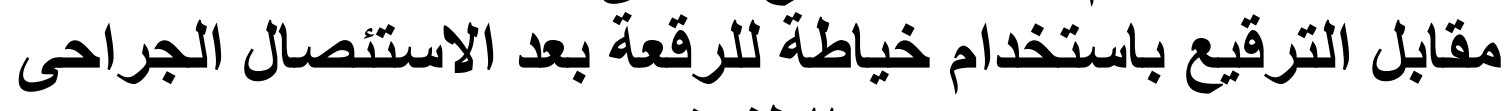 للظظفرة}

محمد خضر محمد، محمد عبد البديع راشد، محمد محمود محمد حسن

قسم طب وجراحة العين، كلية الطب، جامعة الأزهر

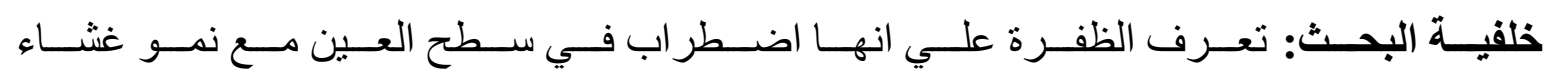
ليفي و عائي على شكل جناح من أنسجة الملتحمة على القرنية.

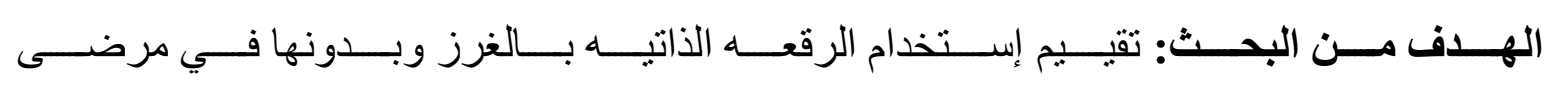
الظفرة.

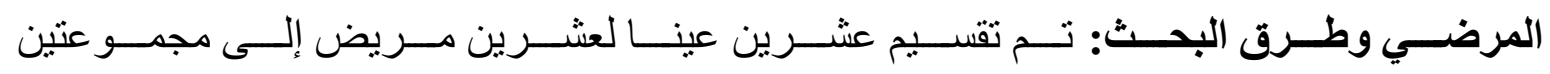

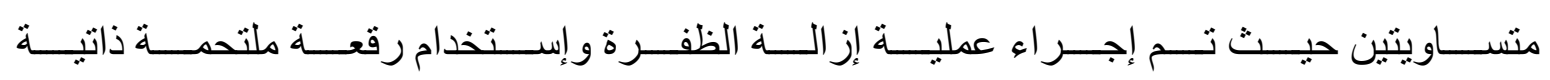

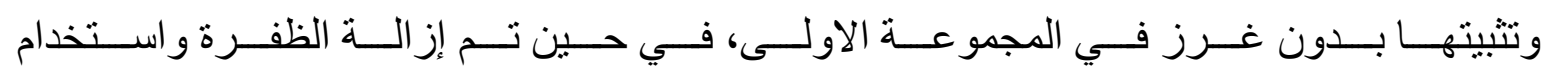

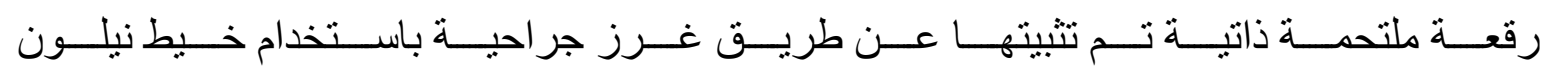
للمجمو عة الثانية.

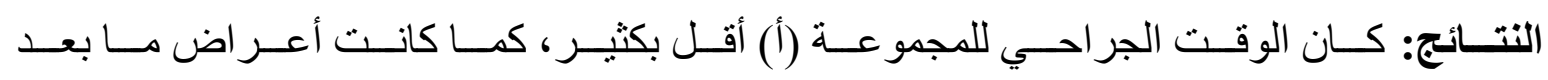

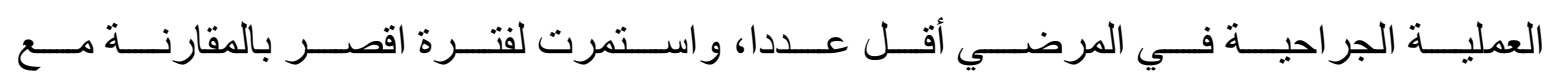

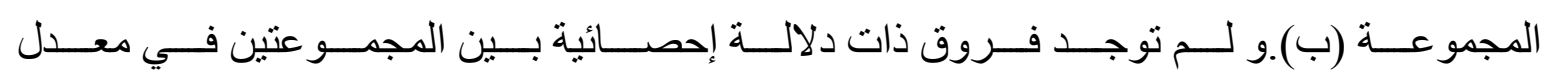

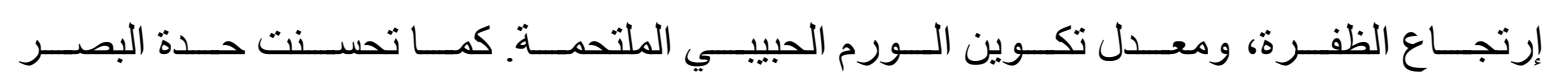

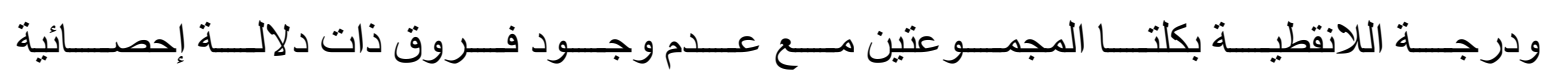
بينهما.

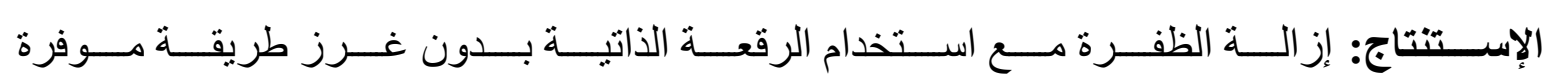
للوقت وفعالة وآمنة و أقل تكلفة. 